\title{
REALISTIC MATHEMATICS EDUCATION APPROACH IN A MULTIPLE INTELLIGENCES PERSPECTIVE OF ELEMENTARY SCHOOL STUDENTS
}

\author{
Sukma Murni ${ }^{1}$, Siti Ruqoyyah ${ }^{2}$ \\ ${ }^{1}$ Institut Keguruan dan Ilmu Pendidikan Siliwangi \\ ${ }^{2}$ Institut Keguruan dan Ilmu Pendidikan Siliwangi \\ 1sukmamurni19@gmail.com, ${ }^{2}$ sitiruqoyyah13@gmail.com
}

\begin{abstract}
The background of this research is that thinking skills and awareness of the importance of mathematics need to be taught and trained to students from an early age because in everyday life many things are related to thinking skills and awareness of the importance of mathematics. The purpose of this study was to determine the effectiveness of teaching materials using the RME approach in the perspective of elementary school students' multiple intelligences. The method used is descriptive qualitative research with the study population is all elementary schools in the city of Cimahi. The instruments used in this study were written tests, observation, and documentation which were carried out at the pretest and posttest stages. The results of the research achieved were an increase in thinking skills and awareness of elementary students in learning mathematics and the availability of teaching materials using the RME approach.
\end{abstract}

Keywords: mathematics learning, multiple intelligences, realistic mathematics education

\begin{abstract}
Abstrak
Latar belakang penelitian ini adalah keterampilan berpikir dan kesadaran terhadap pentingnya matematika sangat perlu diajarkan dan dilatihkan kepada siswa mulai sejak dini karena dalam kehidupan sehari-hari banyak hal yang berkaitan dengan keterampilan berpikir dan kesadaran akan pentingnya matematika. Tujuan penelitian ini adalah untuk mengetahui keefektivitasan bahan ajar menggunakan pendekatan RME dalam perspektif multiple intelligences Siswa Sekolah Dasar. Metode yang digunakan merupakan penelitian kualitatif deskriptif dengan populasi penelitian adalah seluruh SD yang berada di wilayah kota Cimahi. Instrumen yang digunakan pada penelitian ini adalah tes tertulis, observasi dan dokumentasi yang dilaksankan pada tahap pretes dan postes. Hasil penelitian yang dicapai adalah adanya peningkatan keterampilan berpikir dan kesadaran siswa SD pada pembelajaran matematika, dan tersedianya bahan ajar menggunakan pendekatan RME.
\end{abstract}

Kata Kunci: realistic mathematics education, multiple intelligences, pembelajaran matematika.

\section{INTRODUCTION}

The legislation in the country of Indonesia concerning the National Education System emphasizes that mathematics is one of the mandatory lessons that must be taken by all students at every level. The demand for students' abilities in mathematics is logical and critical reasoning ability in problem-solving, not just having the ability to count alone. The purpose of the mathematics lessons mentioned is so that students can understand, use reasoning, solve problems, communicate, and have an attitude of respect for mathematics. Solving this problem is more to the problems faced daily, not just problems in the form of routine problems. Skills in thinking are needed to find and overcome a problem. When a person is faced with a problem that must be resolved, then at that moment thinking skills will emerge. Thinking skills needed 
in solving problems are thinking critically, systematically, logically and creatively. The ability is essential so that students can acquire, manage and utilize information that is always changing. One of the efforts to achieve these goals is through the learning of mathematics ((Murni et al., 2020)(Rohaeti et al., 2019)(Apino \& Retnawati, 2017)(P. H. D. and H. W. Hendriana H, 2019)(P. R. C. I. and H. W. Hendriana H, 2019)(Hendriana et al., 2018)(Sari \& Hidayat, 2019)(Hidayat \& Aripin, 2019)(Hidayat et al., 2018)).

Gardner has emphasized that every individual has 8 intelligences, summarized in multiple intelligences (Gardner, 1998). Namely, linguistic, mathematical, spatial, musical, kinesthetic, interpersonal, intrapersonal, and naturalist intelligence. Thinking skills and awareness of the importance of mathematics really need to be taught and trained to students from an early age because in everyday life many things are related to thinking skills and awareness of the importance of mathematics in everyday life.

The RME approach is expected to minimize the problems described above because it is in accordance with the characteristics of elementary school students who are still happy to play and in accordance with technological developments that have started to spread to elementary school children. Therefore, the title of this study is "Realistic Mathematics Education Approach in a Multiple Intelligences Perspective of Elementary School Students". The specific objectives in this study were to make teaching materials using the RME approach, the availability of teaching materials using the RME approach, and to find out the effectiveness of teaching materials using the RME approach in the perspective of Primary School students' multiple intelligences.

\section{Mathematics Learning in Primary Schools}

Education has an important role in preparing quality human resources and competing in the development of science. Education must be encouraged as best as possible. This can be achieved through timely education to realize learning objectives, which is carried out in the form of a learning process which is the implementation of the school curriculum through teaching activities. Mathematics is an important part that cannot be separated from human life. In the world of education, mathematics is often found in other subjects. Thus, mathematics is called applied science. One of the goals of studying mathematics is to educate the nation's life. Things to consider in mathematics are interest and willingness, and hard work in thinking (Chotimah et al., 2018). 
Mathematics is a subject that is closely related to real life. None of the little things and problems around us require mathematics. The Ministry of National Education (Chotimah et al., 2018) said that mathematics has an important role in developing human thinking so that mathematics becomes the foundation for the development of modern technology. Likewise according to (Ruqoyyah, 2018), mathematics is a science that stands alone but has an important role for other sciences and mathematics is a basic science in the creation of modern and sophisticated technology.Mathematics equips students to have logical, analytical, systematic, critical, and cooperative skills. Therefore, mathematics lessons should be given to all students for every level of education, from elementary to university level.

The scope of mathematics subjects are numbers, data processing, math story problems, geometry, and measurement. Based on the scope of the mathematics subject, the scope of mathematics is an important part that cannot be separated from human life.

\section{Teaching Materials}

Teaching materials are a set of learning tools or tools that contain learning materials, methods, media, and ways of evaluating which are designed systematically and attractively in order to achieve the expected learning objectives, namely achieving competence or subcompetence with all its complexity. Based on this understanding, it is emphasized that the teaching materials will be more meaningful if they are designed with instructional principles by paying attention to competencies and materials that come from the curriculum, are effective, interesting, and involve students. The Ministry of National Education ((Departemen Pendidikan Nasional, 2013)) argues that teaching materials have several characteristics, namely self-instructional, self-contained, stand-alone, adaptive, and user friendly. Teaching materials have various types, some are printed and non-printed. Printed teaching materials that are often found include handouts, books, modules, brochures, and student worksheets.

Student worksheets are teaching materials that have been packaged in such a way that students are expected to be able to learn the teaching material independently. In the LKS, students will get material, summaries, and assignments related to the material. The use of the RME approach in research has been widely implemented, but the use of the RME approach in the perspective of multiple intelligences in elementary mathematics learning is very rare and may not even exist so that in this study as an alternative in improving thinking skills / multiple intelligences and students' awareness of the role of mathematics in life, materials are used. teaching in the form of worksheets using the RME approach. 


\section{Multiple Intelligences}

Gardner has emphasized that every individual has 8 intelligences, summarized in multiple intelligences ((Gardner, 1998)). Namely, linguistic, mathematical, spatial, musical, kinesthetic, interpersonal, intrapersonal, and naturalist intelligence. According to Jasmine, multiple intelligences are the highest validation of the idea that individual differences are important. Its use in education is very dependent on recognizing, recognizing, and appreciating each or the various ways students learn, their interests, and talents (Jasmine, 2007). Fathani emphasized that multiple intelligences exist in every individual, but each individual has only one or more levels of multiple intelligences. However, in the practice of learning in schools, it is appropriate for a teacher to have data on the level of tendencies for each student's multiple intelligences (Fathani, A., 2013).

Society today is required to be able to develop knowledge optimally so that it is smarter and more critical in receiving and processing information. Because this is very important to support solving increasingly complex problems. To answer the needs and demands of the times, education plays an important role in preparing competent future generations, one of which is mastery and understanding of mathematics holistically. Mathematics is used as the foundation for various other scientific developments, especially science and technology. Every individual has a unique intelligence called multiple intelligences, not perfect if you do not have adequate mathematical skills. We must be able to take advantage of mathematics not only theoretically, but also applicatively. All who join mathematics education must continue to make great efforts to improve their mathematical abilities.

\section{Realistic Mathematics Education}

The RME approach is an approach that is oriented towards the mathematicalization of everyday experiences and the application of mathematics in everyday life. Then by exploring real situations students reinvents the mathematical concepts learned. There are two main perspectives in RME and three main principles (Feudenthal, in (Murni, S., \& Sugandi, 2018)). The RME perspective is: mathematics must be linked to reality and mathematics must be seen as a human activity; and the three principles are: guided reinvention, didactic phenomenology, and self-developed models.

Travers and Gravemeijer (Murni, S., \& Sugandi, 2018) suggest that RME has five principles, namely: a) Utilizing context, b) Implementing a model in a mathematization 
progressive; c) Make use of student constructs; d) Interactive; and e) are intertwined. Furthermore, Treffer (as quoted in Fathurrohman, 2015, (Murni, S., \& Sugandi, 2018)) proposes that in solving math problems there are two types of mathematization, namely: horizontal and vertical mathematization.

Similar to the teaching approach, RME has advantages and disadvantages. Suwarsono (Murni, S., \& Sugandi, 2018) provides several benefits of RME such as a) To link mathematics and activities of daily life, b) Mathematics is built and improved by students themselves; c) Mathematics is an open process; d) RME combines the advantages of other approaches based on the philosophy of constructivism such as problem-based learning, problem-based environments, and contextual teaching. Meanwhile, some of the weaknesses of RME include a) Finding good contextual problems is not easy for certain mathematical topics; b) Assessment in RME is more complicated than in conventional teaching; c) To choose the relevant learning media must be careful so that it helps students think.

\section{METHOD}

This research is a descriptive qualitative study that aims to determine the effectiveness of teaching materials using the RME approach in the perspective of elementary school students' multiple intelligences. Withney ((Winarni, E., 2011)) states that descriptive research is appropriate to take a picture of a situation or event. In addition, Sukmadinata ((Sukmadinata, N., 2011)) said that descriptive research is the most basic form of research that aims to describe existing phenomena.

\section{Research Stages}

The steps for research activities that will be carried out are as follows:

1. Formulate problems, develop thinking skills assessment, and students' awareness of the importance of mathematics in everyday life.

2. Provide an overview of the research activities to be carried out.

3. Reflect and discuss various learning activities.

4. Collaborating with elementary schools that will be used as research subjects online.

5. Develop instruments by doing field validation and expert validation.

6. Implementation of learning activities using teaching materials with the online RME approach. 
7. Evaluation of learning activities using teaching materials with the RME approach with written tests, observations, and documentation which are carried out in the pretest, implementation, and posttest. Everything is done online.

8. Withdrawing conclusions from the results of the analysis and data processing obtained in this study.

\section{Research Subjects and Locations}

The population in this study were all fifth-grade students in the city of Cimahi. The reason for choosing a school in the city of Cimahi is that most of the students in SD Cimahi come from various regions in Indonesia so it is assumed that it is appropriate to analyze and improve students' thinking skills and awareness of the importance of mathematics in the perspective of multiple intelligences with daily life.

The sample in research on the analysis of multiple intelligences is class V SDN Setiamanah Mandiri 1 Cimahi and SDN Cibabat Mandiri 1, the number of students is 20 students and is assumed to have relatively the same homogeneous level in terms of location, school culture and the average grade $\mathrm{V}$ grade in mathematics learning. While the sample for the mathematics logic intelligence test was 10-grade students of SDN Setiamanah Mandiri 1 Cimahi.

\section{Research design}

The research design in this study is as follows:

\section{Planning Stage}

a. Analyzing teaching materials, especially teaching materials with the RME approach, which will be used in the learning process.

b. Analyzing multiple intelligence thinking skills.

c. Develop research instruments.

d. Develop learning tools

e. Making teaching materials using the RME approach.

\section{Implementation Stage}

a. Carry out the multiple intelligence thinking skills pretest on the research subject.

b. Implement learning using teaching materials using the RME approach.

\section{Completion Stage}

a. Collecting research data

The data collected is data related to students' multiple intelligence thinking skills. 
b. Analyze research results

The results analyzed were the results of the evaluation of students' multiple intelligence thinking skills.

c. Draw conclusions

Drawing conclusions based on the results of the analysis from data processing.

\section{RESULTS AND DISCUSSION}

\section{Results}

The 3 types of intelligence and each the indicators consists of 7 statements presented in Table 1. The questionnaire consists of five rating scales: rarely, sometimes, often enough, often, and always. The range of scales used is $1-5$, so the lowest score of a student is $7(7 \times 1=7)$ and the highest score is $35(7 \times 5=35)$. Therefore, the median is $(7+35) / 2=21$.

Table 1. Questionnaire grilles

\begin{tabular}{clc}
\hline Type of Intelligence & \multicolumn{1}{c}{ Indicator } & Number Statement \\
\hline $\begin{array}{c}\text { Logical } \\
\text { mathematical }\end{array}$ & $\begin{array}{l}\text { Calculate, measure, and consider propositions and } \\
\text { hypotheses and complete mathematical operations. }\end{array}$ & $1,4,7,10,13,16,19$ \\
Intrapersonal & $\begin{array}{l}\text { Understand yourself from the desires, goals, and } \\
\text { emotional systems that emerge clearly in his work. }\end{array}$ & $2,5,8,11,14,17,20$ \\
Interpersonal & $\begin{array}{l}\text { Understanding and communicating with others is seen } \\
\text { from differences, temperament, motivation, and } \\
\text { ability. }\end{array}$ & $3,6,9,12,15,18,21$ \\
\end{tabular}

The logical-mathematical, intrapersonal, and interpersonal intelligence questionnaire scores were categorized on a scale of 5 using the Normative Reference Assessment approach presented as follows Table 2 .

Table 2. Multiple intelligences category

\begin{tabular}{ccc}
\hline Score Interval & Score & Information \\
\hline 29 and above & A & Very High \\
$22-28$ & B & High \\
$15-21$ & C & Medium \\
$8-14$ & D & Low \\
7 and below & E & Very Low \\
\hline
\end{tabular}


The following is a recapitulation of the results of the analysis of 3 intelligences, namely logicalmathematical, intrapersonal, and interpersonal.

Table 3. Recapitulation of Multiple Intelligences Analysis Results

\begin{tabular}{ccccccccc}
\hline Score Interval & Score & Information & $\begin{array}{c}\text { Logical- } \\
\text { Mathematical } \\
\text { Frequency }\end{array}$ & $\begin{array}{c}\text { Percentage } \\
(\%)\end{array}$ & $\begin{array}{c}\text { Intrapersonal } \\
\text { Frequency }\end{array}$ & $\begin{array}{c}\text { Percentage } \\
(\%)\end{array}$ & $\begin{array}{c}\text { Interpersonal Percentage } \\
\text { Frequency }\end{array}$ & (\%) \\
\hline 29 and above & A & Very High & 2 & 10 & 2 & 10 & 2 & 10 \\
$22-28$ & B & High & 5 & 25 & 4 & 20 & 3 & 15 \\
$15-21$ & C & Medium & 10 & 50 & 10 & 50 & 6 & 30 \\
$8-14$ & D & Low & 2 & 10 & 2 & 10 & 6 & 30 \\
7 and below & E & Very Low & 1 & 5 & 2 & 10 & 3 & 15 \\
\hline
\end{tabular}

Based on the calculation of the average value of the questionnaire score of 17.5 are in the moderate category and 17.33 are in a low category compared to the intrapersonal intelligence category, then the average value of the majority is in the moderate and low category. So, it can be concluded that the intrapersonal intelligence of Elementary School Students is in medium and low categories.

It can be seen that the test scores of each intelligence vary. Observing this, mathematical thinking skills have greater variation influenced by different combinations of intelligence in each individual. There is no individual in the same combination of intelligence. Gardner (Gardner, 1998) says that we are all so different mainly because we all have different combinations of intelligence. In addition, the results of research conducted by Kartikasari and Widjajanti (Kartikasari \& Widjajanti, 2017) showed that at the 5\% significance level, learning by problem-based learning approach based on Gardner's multiple intelligences effective in terms of student's achievement, the mathematical connection capability, and self-esteem of students. However, although there are some problems have been effective on achievement tests and mathematical connection test result which have low achievement.

After analyzing the students' multiple intelligences, then before and after being given learning using the RME approach, students were given a pretest and posttest to find out to what extent they could solve the questions before and after learning was applied by the teacher. The multiple intelligence indicator taken in this pretest and posttest is mathematical logic intelligence, with a total of 10 questions. The following is the recapitulation, 
Table 4. Recapitulation of Logical-Mathematical Pretest-Posttest Results

\begin{tabular}{|c|c|c|c|c|}
\hline Number & Name & Pretest & Posttest & Percentage \\
\hline 1 & S1 & 41 & 84 & 43 \\
\hline 2 & S2 & 27 & 76 & 49 \\
\hline 3 & $\mathrm{~S} 3$ & 22 & 66 & 44 \\
\hline 4 & S4 & 23 & 70 & 47 \\
\hline 5 & S5 & 29 & 84 & 55 \\
\hline 6 & S6 & 27 & 79 & 52 \\
\hline 7 & S7 & 24 & 73 & 49 \\
\hline 8 & S8 & 27 & 77 & 50 \\
\hline 9 & S9 & 23 & 72 & 49 \\
\hline 10 & $\mathrm{~S} 10$ & 28 & 80 & 52 \\
\hline \multicolumn{2}{|c|}{ Average } & 27,1 & 76,1 & 49 \\
\hline
\end{tabular}

Based on Table 4, it can be seen that all students experienced an increase in the achievement of test scores from pretest to posttest. The average pretest and posttest results are 27.1 and 76.1 , this indicates that there is an increase in achievement by $49 \%$. This means that learning using RME approach teaching materials from the perspective of SD students' multiple intelligences is very effective to apply.

\section{Discussion}

Before carrying out the research, researchers conducted a survey of elementary schools in Cimahi City. Then prepare the tools for conducting research, such as making teaching materials, making instruments, validating instruments, making lesson plans, and others.

Furthermore, the researcher conducted an analysis of multiple intelligences for elementary school students in two schools, namely the fifth-grade students of SDN Setiamanah Mandiri 1 Cimahi and SDN Cibabat Mandiri 1, each of which was taken 10 students. The results of the analysis have been previously explained, then the researchers compiled the teaching materials using the RME approach from the perspective of multiple intelligences before carrying out the learning.

The following are the stages of preparing teaching materials using the RME approach in the perspective of students' multiple intelligences in mathematics learning in elementary school:

1. Create a concept for the preparation of teaching materials

2. Collect literature studies

3. Develop teaching materials 
4. Expert validation of the teaching materials that have been prepared

5. Editing of validated teaching materials

6. Creating a cover design for teaching materials

7. Print teaching materials

8. Registering teaching materials to the ISBN

9. Publish teaching materials that have an ISBN

10. Registering Intellectual Property Rights (HKI) from the teaching materials that have been prepared.

The school that was taken for the next implementation was SDN Setiamanah Mandiri 1 Cimahi with a total of 10 students. A pretest was carried out before the implementation of learning activities, with results that were still low because students had never received the material tested. After that, learning was carried out with teaching materials using the RME approach from the perspective of multiple intelligences. The last activity is post-test, post-test results show improvement and better overall achievement.

\section{CONCLUSION}

Based on the results of the study it can be concluded that: (1) Mathematical logic intelligence based on multiple intelligences of elementary school students in Cimahi in 2020 is in the sufficient category. It is also known that students' mathematical thinking skills vary greatly, due to a combination of different bits of intelligence between one student and another student; (2) Intrapersonal intelligence based on multiple intelligences of elementary school students in Cimahi in 2020 is in the sufficient category; (3) Interpersonal intelligence based on multiple intelligences of elementary school students in Cimahi 2020 is in the moderate and low categories; (4) Learning using RME approach teaching materials in the perspective of SD students' multiple intelligences is very effective to apply.

\section{ACKNOWLEDGMENTS}

We would like to thank the RISTEK-BRIN and LPPM IKIP Siliwangi for supporting us to take part in this journal published.

\section{REFERENCES}

Apino, E., \& Retnawati, H. (2017). Developing Instructional Design to Improve Mathematical Higher Order Thinking Skills of Students. Journal of Physics: Conference Series. https://doi.org/10.1088/1742-6596/812/1/012100 
Chotimah, S., Bernard, M., \& Wulandari, S. M. (2018). Contextual approach using VBA learning media to improve students' mathematical displacement and disposition ability. Journal of Physics: Conference Series. https://doi.org/10.1088/1742-6596/948/1/012025

Departemen Pendidikan Nasional. (2013). Dokumen Kurikulum 2013. Depdiknas.

Fathani, A., H. (2013). Gaya Belajar Siswa dalam Menyelesaikan Masalah Matematik Ditinjau dari Tingkat Kecenderungan Kecerdasan Matematik dan Linguistik. Prosiding Seminar Nasional Matematika Dan Pendidikan Matematika, 18 Mei 2013.

Gardner, H. (1998). Multiple Intelligences: The Theory in Practice. BasicBooks.

Hendriana, H., Hidayat, W., \& Ristiana, M. G. (2018). Student teachers' mathematical questioning and courage in metaphorical thinking learning. Journal of Physics: Conference Series. https://doi.org/10.1088/1742-6596/948/1/012019

Hendriana H, P. H. D. and H. W. (2019). How to Design Teaching Materials to Improve the Ability of Mathematical Reflective Thinking of Senior High School Students in Indonesia? EURASIA J. Math. Sci. Technol. Educ., 15(1790).

Hendriana H, P. R. C. I. and H. W. (2019). The innovation of learning trajectory on multiplication operations for rural area students in Indonesia. J. Math. Educ, 10, 397408.

Hidayat, W., \& Aripin, U. (2019). The improvement of students' mathematical understanding ability influenced from argument-driven inquiry learning. Journal of Physics: Conference Series. https://doi.org/10.1088/1742-6596/1157/3/032085

Hidayat, W., Wahyudin, \& Prabawanto, S. (2018). Improving students' creative mathematical reasoning ability students through adversity quotient and argument driven inquiry learning. Journal of Physics: Conference Series. https://doi.org/10.1088/17426596/948/1/012005

Jasmine, J. (2007). Professional's Guide: Teaching with Multiple Intelligences. Terjemahan oleh Purwanto (Panduan Praktis Mengajar Berbasis Multiple Intelligences). Nuansa.

Kartikasari, A., \& Widjajanti, D. B. (2017). The Effectiveness of Problem-Based Learning Approach Based on Multiple Intelligences in Terms of Student's Achievement, Mathematical Connection Ability, and Self-Esteem. Journal of Physics: Conference Series. https://doi.org/10.1088/1742-6596/812/1/012097

Murni, S., \& Sugandi, A. I. (2018). The Role of Mathematics Realistic Education Approach on Students'mathematical Critical Thinking and Resiliency. JIML-Journal of Innovative Mathematics Learning, 1(1), 41-52.

Murni, S., Bernard, M., Ruqoyyah, S., \& Chotimah, S. (2020). PGSD student's mathematical creative thinking skills judging from creativity quotations by making vba-based teaching. Journal of Physics: Conference Series. https://doi.org/10.1088/1742$6596 / 1521 / 3 / 032040$

Rohaeti, E. E., Nurjaman, A., Sari, I. P., Bernard, M., \& Hidayat, W. (2019). Developing didactic design in triangle and rectangular toward students mathematical creative thinking through Visual Basic for PowerPoint. Journal of Physics: Conference Series. https://doi.org/10.1088/1742-6596/1157/4/042068

Ruqoyyah, S. (2018). Meningkatkan Kemampuan Komunikasi Matematik Siswa MA Melalui Contextual Teaching And Learning. P2M STKIP Siliwangi, 5(2), 85-99. 
Journal of Elementary Education

Volume 4, Number 2, September 2020

P-ISSN: 2580-9326

E-ISSN: 2580-7714

Sari, V. T. A., \& Hidayat, W. (2019). The students' mathematical critical and creative thinking ability in double-loop problem solving learning. Journal of Physics:

Conference Series. https://doi.org/10.1088/1742-6596/1315/1/012024

Sukmadinata, N., S. (2011). Metode Penelitian Pendidikan. Rosdakarya.

Winarni, E., W. (2011). Penelitian Pendidikan. FKIP UNIB. 